\title{
Analisis Disiplin Kerja Guru SMK Swasta Taruna Pekanbaru
}

\author{
Yulia Harwina \\ Sekolah Tinggi Ilmu Ekonomi Riau (STIER) \\ Jln. HR. Subrantas 57 Panam Pekanbaru 28293 Telp. (0761) 63237 \\ E-mail : yulia_harwina@yahoo.com
}

\begin{abstract}
Labor discipline is business as management implementation guidelines to strengthen the organization in achieving its intended purpose. The better the teacher labor discipline in terms of providing a form of business confidence for menuakinkan in order to understand the rules that exist in schools and also strive to adhere to the rules defined. Then have a keen desire to change is a positive attitude or also repairs done continuously by teachers in order to improve discipline in work. Also in the sacrifice of the efforts of teachers in making the work done iklas follow the rules that exist and also the attitude of openness in their duties. In terms of the value achieved is the result obtained in the form of real action of a teacher and an attitude of self-discipline that views of his actions every day as well as the achievement is the result of discipline that can be seen from the extent of the violations committed and compliments received by teachers in the discipline.
\end{abstract}

Keywords: Work Discipline Vocational Teachers

Sekolah sebagai lembaga pendidikan formal cukup berperan dalam meningkatkan kualitas generasi muda yang cerdas dan berkepribadian dan dapat digunakan sebagai bekal untuk manjalankan kehidupan di masa depan. Bekal berupa ketrampilan atau skill sangat dibutuhkan generasi ke depan. Kebijakan pemerintah mengenai percepatan keberhasilan bidang pendidikan adalah dengan menetapkan dan menargetkan $60 \%$ SMK berbanding $40 \%$ SMA. Alasannya adalah pendidikan SMK adalah pendidikan kejuruan dan pada dasarnya lembaga pendidikan tersebut ingin mencetak tenaga kerja siap pakai dan siap bekerja di dunia pekerjaan.

SMK memberikan skill kepada peserta didik secara teknis, penerapan pola pendidikannya juga berbeda dengan SMA dimana lebih banyak praktek bila dibandingkan dengan teori. Hal inilah yang membuat beda dan menjadikan lulusan SMK siap pakai dan juga siap menghadapi dunia kerja yang dibutuhkan saat ini. Kondisi perkembangan SMK dan SMA Swasta di daerah ini masih belum memadai. Berdasarkan data dapat diketahui perbandingannya mencapai 49\% SMA, sedangkan SMK masih sebanyak $51 \%$.
Berikut ini data tentang prosentase SMA dan SMK di Kota Pekanbaru.

Berbagai macam pola pendidikan yang diterapkan pada tingkat SMK dengan berbagai jurusan dan keahlian yang ditawarkan kepada peserta didik memberikan warna tersendiri dalam dunia pendidikan saat ini. Hal ini dapat dilihat dari model teori yang diterapkan, model praktek dengan menjalin kerjasama dengan berbagai dunia kerja dan juga penerapan model disiplin kepada siswa yang semi militer. Melalui berbagai pola dan model yang pembelajaran kepada siswa ini diharapkan akan terwujud siswa yang memiliki kompetensi baik kompetensi dalam pengetahuan maupun kompetensi dalam bentuk sikap disiplin.

Pola semi militer menjadi salah satu fenomena yang menarik dipelajari, dimana beberapa SMK yang berkembang di Kota Pekanbaru menerapkan pola semi militer. Berseragam selayaknya militer dan juga bersikap dan latihan-latihan semi militer diterapkan kepada siswa agar siswa memiliki kedisiplinan diri dan memiliki sikap bertanggung jawab dalam mengemban tugas yang diberikan.

Dalam pelaksanaannya dan untuk mencapai tujuan tersebut, peran guru 
sangat besar. Guru menurut UndangUndang Nomor 14 Tahun 2005 adalah pendidik profesional dengan tugas utama mendidik, mengajar, membimbing, mengarahkan, melatih, menilai, dan mengevaluasi peserta didik pada pendidikan anak usia dini jalur pendidikan formal, pendidikan dasar, dan pendidikan menengah. Peranan guru sangat penting dalam dunia pendidikan karena selain berperan mentransfer ilmu pengetahuan ke peserta didik, guru juga dituntut memberikan pendidikan karakter dan menjadi contoh karakter yang baik bagi anak didiknya.

Harapan yang diinginkan masyarakat terhadap dunia pendidikan adalah pendidikan yang berkualitas, pendidikan yang berkualitas tidak terlepas dari peran guru dalam melaksanakan tugasnya. Sebab guru sebagai pelaksana terdepan atau ujung tombak terlaksananya kegiatan belajar mengajar di sekolah. Berhasil atau tidaknya upaya peningkatan mutu pendidikan banyak ditentukan oleh kompetensi yang ada pada mereka tersebut dalam mengembangkan tugas pokok seharihari.

Guru dengan jenis pekerjaan ini tidak dapat dilaksanakan kebanyakan orang di luar pendidikan. Keahlian khusus yang dimaksud adalah upaya penanganan yang lebih spesifik dan perlunya kecermatan yang mendalam. Hal ini dapat dilihat dari beberapa tugas guru diantaranya mendidik, mengajar dan melatih. Mendidik berarti meneruskan dan mengembangkan nilainilai hidup, kemudian mengajar berarti meneruskan dan mengembangkan ilmu pengetahuan dan teknologi, selanjutnya melatih berarti mengembangkan keterampilan melalui minat, bakat dan kreativitas.

Seorang guru menyadari bahwa titik pusat tujuan sekolah menyediakan program pendidikan yang direncanakan untuk memenuhi kebutuhan hal-hal yang berkaitan dengan pendidikan, pribadi dan kebutuhan kemasyarakatan serta kepentingan individu para siswa. Siswa merupakan klien utama yang harus dilayani, oleh sebab itu siswa harus dilibatkan secara aktif dan tepat, tidak hanya dalam proses belajar mengajar melainkan juga di dalam kegiatan sekolah.

Permasalahan yang dilihat dari observasi lapangan mengenai kinerja guru SMK Swasta Taruna di Kota Pekanbaru dapat dilihat dari data berikut ini: Guru dalam mendidik belum mampu menjadi contoh kepada peserta didik sebagaimana konsep taruna satria dalam hal disiplin baik dalam disiplin waktu maupun dalam bentuk disiplin perilaku. Kondisi ini dapat dilihat dari guru yang datang ke sekolah terlambat dan juga berpakaian belum rapi sebagaimana standar berpakaian yang diatur dalam standar berpakaian. Selain itu dalam berperilaku masih belum mampu memberikan contoh yang seharusnya kepada peserta didik seperti berkata kasar dan juga kurang bertanggung jawab.

$$
\text { Menurut Anwar Prabu }
$$

Mangkunegara (2013: 129) disiplin kerja dapat diartikan sebagai pelaksanaan manajemen untuk memperteguh pedomanpedoman organisasi. Dijelaskan disiplin terbagi menjadi dua yakni disiplin preventif dan disiplin korektif. Disiplin preventif adalah suatu sistem yang berhubungan dengan kebutuhan kerja untuk semua bagian sistem yang ada dalam organisasi. Kemudian disiplin korektif adalah suatu upaya menggerakkan pegawai dalam menyatukan suatu peraturan dan mengarahkan untuk tetap mematuhi peraturan sesuai dengan pedoman yang berlaku pada organisasi.

Kemudian menurut Panji Anoraga (2009: 46) disiplin adalah suatu sikap, perbuatan untuk selalu mentaati tata tertib. Pada pengertian disiplin juga tersimpul dua factor yang penting yaitu faktor waktu dan kegiatan atau perbuatan. Menurut Scott Snair (2008: 129) menyatakan kedisiplinan terjamin, maka harus dilakukan secepat mungkin, semakin dekat jarak antara hukuman dan pelanggaran semakin besar 
dampak yang ditinggalnya terhadap orangorang yang diluruskan dan ingat bahwa tujuan akhir dari imbalan dan hukuman adalah mengatur dan mengarahkan perilaku agar bisa mencapai tujuan kelompok.

Menurut Mangkunegara (2000: 129) disiplin kerja kerja dapat diartikan sebagai pelaksanaan manajemen untuk memperteguh pedoman-pedoman organisasi. Disiplin pada hakekatntya adalah kemampuan untuk mengendalikan diri dalam bentuk tidak melakukan sesuatu tindakan yang tidak dan bertentangan dengan sesuatu yang telah ditetapkan dan melakukan sesuatu yang mendukung dan melindungi sesuatu yang telah ditetapkan.

Menurut Sedarmayanti (2001: 10) disiplin merupakan salah satu fungsi manajemen sumber daya manusia yang penting dan merupakan kunci terwujudnya tujuan, karena tanpa adanya disiplin maka sulit mewujudkan wujuan yang maksimal. Melalui disiplin pula timbul keinginan dan kesadaran untuk mentaati peraturan organisasi dan norma social. Namun tetap pengawasan terhadap pelaksanaan disiplin tersebut perlu dilakukan.

Menurut Muhaimin (2008: 57) nilai disiplin adalah suatu nilai yang harus dimaknai sebagai kemajuan untuk mengerjakan yang prioritas dan mengerjakannya sampai tuntas. Berdasarkan pendapat di atas, maka dapat disimpulkan disiplin kerja adalah usaha yang sebagai pelaksanaan manajemen untuk memperteguh pedoman-pedoman organisasi dalam mencapai tujuan yang telah ditetapkan.

Menurut Anwar Prabumangkunegara (2013: 137) dimensi disiplin kerja antara lain: 1) memberikan kepercayaan; 2) memiliki keinginan ingin berubah; 3) pengorban; 4) nilai yang dicapai; 5) pencapaian. Berdasarkan uraian di atas maka dimensi disiplin adalah memberikan kepercayaan; memiliki keinginan ingin berubah; pengorban; nilai yang dicapai; pencapaian.

- memberikan kepercayaan merupakan adanya usaha yang dilakukan dalam mematuhi aturan yang berlaku.
- memiliki keinginan ingin berubah merupakan usaha memperbaiki diri secara terus menerus.

- pengorban merupakan tindakan dalam mematuhi aturan yang ada dalam organisasi.

- nilai yang dicapai merupakan manfaat yang diperoleh dari adanya tindakan atau sikap disiplin itu sendiri.

- pencapaian merupakan hasil kerja yang dicapai dalam bentuk penilaian.

\section{METODE}

Populasi menurut Sugiono (2009: 235) adalah wilayah generalisasi yang terdiri atas obyek, subyek yang mempunyai kualitas dan karakteristik tertentu yang ditetapkan oleh peneliti untuk dipelajari kemudian ditarik kesimpulanya. Populasi dalam penelitian ini adalah seluruh guru SMK Taruna swasta di Kota Pekanbaru yang berjumlah 3 sekolah yakni SMK Masmur, SMK Taruna Satria dan Pelayaran yang seluruhnya berjumlah 92 orang. Menurut M Nasution dalam penelitian tidak ada ketentuan pasti berapa jumlah sampel yang mesti diambil, namun sampel yang diambil untuk kegiatan penelitian haruslah memenuhi unsur representative (mewakili jumlah populasi) serta mencerminkan keadaan populasi secara keseluruhan. Sampel adalah bagian dari jumlah dan karakteristik yang dimiliki oleh populasi. Jumlah populasi dalam penelitian ini adalah 92 orang, dianggap masih memungkinkan untuk diteliti secara keseluruhan oleh sebab itu jumlah populasi dalam penelitian ini sekaligus menjadi sampel penelitian.

Metode pengambilan sampel dilakukan dilakukan dengan simple random sampling. Adalah teknik pengumpulan data yang dilakukan secara langsung pada lokasi penelitian. Pengumpulan data primer dilakukan dengan instrumen kuesioner. Teknik analisis data yang digunakan dalam penelitian ini adalah dengan teknik deskriptif, yakni dengan menggambarkan kondisi disiplin kerja guru SMK. 


\section{HASIL}

Sekolah Menengah Kejuruan (SMK) Taruna merupakan salah satu sekolah kejuruan yang mempersiapkan anak didiknya untuk dapat meningkatkan kecerdasan, pengetahuan, kepribadian, akhlak mulia, dan keterampilan untuk hidup mandiri serta dapat mengikuti pendidikan lebih lanjut di bidang ketrampilan teknis. Sejak awal pendiriannya SMK Taruna telah memiliki komitmen yang kuat untuk menjadi lembaga pendidikan dan pelatihan yang bermutu dan profesional serta mampu berprestasi berwawasan internasional sejalan dengan tuntutan ilmu pengetahuan dan perkembangan teknologi dengan berpegang teguh pada visi/misi sekolah serta nilai - nilai luhur agama dan budaya.

Keunggulan sekolah SMK Taruna adalah menyelenggarakan pendidikan perbengkelan dengan program pengembangan diri ke mesin sepeda motor, mobil, sipil dan elektro serta bisnis dengan sarana dan fasilitas pendidikan yang dirancang untuk memberikan suasana yang nyaman, kondusif dan mampu merangsang niat belajar yang tinggi bagi peserta didik. Fasilitas ruang belajar dan laboratorium perbengkelan memiliki fasilitas lengkap dengan penataan seperti keadaan sebenarnya.

SMK Taruna juga bekerjasama dengan perusahaan-perusahaan di Pekanbaru termasuk dalam peningkatan keterampilan siswa khusunya untuk kegiatan praktek kerja industri Taruna, terbukti pula dengan peningkatan animo masyarakat untuk mengikuti pendidikan di SMK Taruna.

Guru-guru pelajaran produktif yang mengajar untuk pengembangan keterampilan kompensasidi dunia industri, berasal dari para praktisi. Guru-guru pelajaran adaptif dan normatif pelajaran lain juga memiliki kompensasidan kualifikasi yang sesuai dengan mata pelajaran yang diajarkannya

SMK Taruna juga memberikan dukungan yang kondusif untuk pengembangan kemampuan siswa dalam berprestasi. Kegiatan ekstrakurikuler yang disediakan beragam seperti olah raga antara lain sepak bola, basket, volly, atletik, dan silat, di bidang kesenian seperti tari, serta ekstra yang berkaitan dengan pelajaran pengembangan diri yaitu jugling dan extra wajib yang harus diikuti oleh seluruh siswa yaitu PMR dan pramuka.

SMK Taruna berprinsip, seorang siswa selain mengembangkan kemampuan akademiknya juga perlu mengembangkan semua potensi yang dimilikinya guna kehidupan mereka dimasa datang. Untuk mewujudkan hal tersebut SMK Taruna selalu terus menyempurnakan sarana, fasilitas dan SDM nya guna memberikan hasil terbaik bagi siswa didik dan masyarakat.

Disiplin kerja adalah usaha yang sebagai pelaksanaan manajemen untuk memperteguh pedoman-pedoman organisasi dalam mencapai tujuan yang telah ditetapkan. dimensi disiplin kerja antara lain: memberikan kepercayaan merupakan bentuk usaha untuk menuakinkan dalam rangka mengetahui akan aturan yang ada dalam sekolah dan juga berusaha untuk mematuhi aturan yang ditetapkan tersebut. memiliki keinginan ingin berubah merupakan sikap positif atau juga perbaikan yang dilakukan secara terus menerus oleh guru dalam rangka meningkatkan kedisiplinan dalam bekerja. Pengorban merupakan usaha yang dilakukan guru dalam menjadikan pekerjaannya dilakukan secara iklas mengikuti aturan yang ada dan juga sikap keterbukaannya dalam menjalankan tugasnya. nilai yang dicapai merupakan hasil yang diperoleh dalam bentuk tindakan nyata seorang guru dan sikap disiplin diri yang dilihat dari tindakannya setiap hari. Pencapaian merupakan hasil kedisiplinan yang dapat dilihat dari sejauhmana pelanggaran yang dilakukan dan pujian yang diterima guru dalam menegakkan disiplin.

Berdasarkan hasil penelitian dapat diketahui dari jawaban guru terhadap pernyataan bahwa skor atau tingkat capaian rata-rata (TCR) disiplin guru pada SMK Taruna di Pekanbaru berada pada tingkat cukup dengan nilai 3,11 atau TCR 77,7\%. Jawaban tertinggi terletak pada item 
Sekolah mendapatkan pujian dari masyarakat atas penerapan disiplinnya. Sedangkan item terendah pada bertindak sesuai aturan yang berlaku.

\section{PEMBAHASAN}

Disiplin kerja adalah usaha yang sebagai pelaksanaan manajemen untuk memperteguh pedoman-pedoman organisasi dalam mencapai tujuan yang telah ditetapkan. Semakin baik disiplin kerja guru dalam hal memberikan kepercayaan merupakan bentuk usaha untuk menuakinkan dalam rangka mengetahui akan aturan yang ada dalam sekolah dan juga berusaha untuk mematuhi aturan yang ditetapkan tersebut. Kemudian memiliki keinginan ingin berubah merupakan sikap positif atau juga perbaikan yang dilakukan secara terus menerus oleh guru dalam rangka meningkatkan kedisiplinan dalam bekerja. Juga dalam pengorbanan merupakan usaha yang dilakukan guru dalam menjadikan pekerjaannya dilakukan secara iklas mengikuti aturan yang ada dan juga sikap keterbukaannya dalam menjalankan tugasnya. Dalam hal nilai yang dicapai merupakan hasil yang diperoleh dalam bentuk tindakan nyata seorang guru dan sikap disiplin diri yang dilihat dari tindakannya setiap hari serta pencapaian merupakan hasil kedisiplinan yang dapat dilihat dari sejauhmana pelanggaran yang dilakukan dan pujian yang diterima guru dalam menegakkan disiplin.

Maka akan semakin baik kinerja guru adalah capaian atau hasil kerja dari pelaksanaan tugas sebagai guru yakni dalam melaksanakan tugas mendidik, mengajar, membimbing, mengarahkan, melatih, menilai dan mengevaluasi peserta didik. Seperti dalam mendidik merupakan tindakan memberikan teladan, bertanggung jawab, sikap mandiri dan berwibawa kepada peserta didik, mengajar merupakan memberikan pengetahuan kepada peserta didik berlandaskan bahan ajar dan kesesuaiannya sehingga peserta didik mendapatkan pelajaran yang terarah sesuai dengan kompetensinya. Membimbing dan mengarahkan merupakan bentuk bantuan kepada siswa, memahami siswa, pengarahan diri dan menyesuaikan diri terhadap situasi dan kondisi pembelajaran dilakukan. Melatih merupakan upaya yang dilakukan dalam meninggkatkan ketrampilan peserta didik dalam meningkatkan kecerdasan intelektual dan motorik. menilai merupakan bentuk dalam evaluasi terhadap siswa yang dilakukan dengan memberikan penilaian secara psikologi terhadap perilaku dan juga mental dan mengevaluasi peserta didik merupakan kebijakan yang dilakukan guru dalam rangka meningkatkan pengalaman peserta didik dalam proses belajar mengajar di sekolah.

Hal ini sejalan dengan yang dikatakan Fatchurrohman (2009) bahwa dampak sertifikasi terhadap kinerja para guru di SMP Negeri 1 kota Salatiga cukup positif terhadap guru-guru yang memperoleh sertifikat pendidik, baik pada kedisiplinan kerja dan kedisiplinan administratif akademik. Pada sisi lain, program sertifikasi guru tertentu kurang berdampak terhadap kinerja para guru yang belum mendapatkannya. Mereka biasabiasa saja dalam bekerja, tidak terjadi peningkatan yang berarti akibat program sertifikasi guru. Kemudian juga Jasril (2004) bahwa kinerja guru SLTP dalam melaksanakan tugasnya dipengaruhi oleh factor disiplin dan motivasi kerja baik secara parsial maupun secara simultan

\section{SIMPULAN}

Berdasarkan hasil penelitian maka dapat ditarik kesimpulan bahwa disiplin guru Guru berpengaruh positif dan signifikan terhadap kinerja guru SMK Taruna di Kota Pekanbaru.

\section{DAFTAR RUJUKAN}

Anwar Prabu Mangkunegara, 2013, Manajemen Sumber Daya Manusia Perusahaan, Rosda Karya, Bandung 
Hasibuan, Malayu SP, 2003. Manajemen Sumber Daya Manusi, Edisi Revisi. Jakarta: PT. Bumi Aksara.

Mangkunegara, AA. Anwar Prabu, 2006, Evaluasi Kinerja SDM, Remaja Rosda Karya, Bandung.

Mangkunegara, Anwar Prabu, 2009. Manajemen Sumber Daya Manusia, Remaja Rosda Karya, Bandung.

Moeheriono, 2012, Indikator Kinerja Utama Cetakan $K e-2$, PT. Raja Grafindo Persada, Jakarta.

Muhaimin, 2008, Manajaemen Pendidikan, penerbit Pernada Media Group, Jakata.
Sedarmayanti, 2001, Sumberdaya Manusia dan Produktivitas Kerja, Mandar Maju, Bandung

Sugiyono, 2005, Metode Penelitian Administrasi, Bandung.

Alphabeta,

Fatchurrohman, 2009, Pengaruh disiplin terhadao Kinerja Guru SMP Negeri 1 Salatiga

Undang-undang RI No. 14 tahun 2005 tentang guru dan dosen

Peraturan Menteri Pendidikan Nasional Republik Indonesia Nomor 16 Tahun 2007 tentang Standar Kualifikasi Akademik dan Kompetensi Guru 